\title{
Religion, Politics and the Social Capital of Children
}

\author{
Amanda Friesen, Indiana University-Purdue University Indianapolis \\ SUMMARY. Using a national dataset, this study demonstrates that religious \\ traditionalism and political conservatism are positively related to family size and the \\ interactions between these measures result in increased political participation. Combining \\ the social capital of children and religiosity, these findings suggest that choosing to have \\ more children may be based on beliefs about traditional gender roles and the importance \\ of family in society, which in turn, results in political engagement around these issues.
}

KEYWORDS. Religion, Social Capital, Children, Political Participation

This is the author's manuscript of the article published in final edited form as:

Friesen, A. (2013). Religion, Politics, and the Social Capital of Children. Journal of Women, Politics \& Policy, 34(3), 197-218. Available from: http://dx.doi.org/10.1080/1554477X.2013.805100 
Low voter turnout in the United States raises concerns about possible barriers to political participation and interest. These barriers become more problematic if they disproportionately affect one group of people, which seems to be the case with one of the most fundamental elements of the human condition - childbearing. Traditionally, the responsibility of rearing children has been viewed as a significant obstacle to participating in politics, especially for women, as they continue to contribute more hours to child care and associated household chores (Campbell et al. 1960; Nomaguchi and Milkie 2003; Verba, Schlozman, and Brady 1995). The extent of these obstacles may be affected by whether a woman works outside of the home, the age of children and, especially, the number of children in need of care. This article is specifically concerned with the latter - how much does the addition of children affect one's political participation?

Some of the highest fertility rates in the United States occur in areas with higher concentrations of evangelical Christians ${ }^{1}$ or Mormons (Lesthaeghe and Neidert 2006), at the individual level, though individually evangelical Christians only have slightly more children than those of other faith traditions (Hout, Greeley and Wilde 2001; Lehrer 2004; Mosher, Williams, and Johnson 1992). Their families may not be larger than most, but the presence of children in the home may affect political engagement differently for evangelical mothers as compared to their peers. The involvement of women in forming the Christian Right (Critchlow 2005; Klatch 1988) and the possibility of overcoming the political barrier of raising children with sufficient political interest (High-Pippert 1999) suggest that the same family values which lead to having more children may translate into a type of social capital that leads to political engagement (Lim and Putnam 2010; Offer and Schneider 2007; Smidt et al. 2003; Everitt 2006). Specifically, the 
interaction between an individual's religiosity and his or her number of children may influence political participation.

\section{GENDER AND POLITICAL ENGAGEMENT}

Political engagement and participation require time, energy, interest, and resources - which lead scholars to refer to these factors as "costs” or "barriers.” Because the costs of participation are high, any number of obstacles may prevent individuals from engaging in politics - from taking time off of work and having adequate transportation for voting to being informed of political matters and developing civic skills (Burns, Schlozman, and Verba 2001; Lewis-Beck et al. 2008; Verba, Schlozman, and Brady 1995). These costs disproportionately affect those of lower socioeconomic status, racial minorities, and women. Most of the literature on the political costs of childbearing argue that these barriers are tied to traditional gender roles and the historic lag of female participation or childcare challenges associated with low socioeconomic status (Burns, Schlozman, and Verba 2001; Campbell et al. 1960; Gidengil, O’Neill, and Young 2010; Sapiro 2006; Verba, Schlozman and Brady 1995). Gender roles are not as clearly separated as they once were, though recent studies have reinforced that even with both parents working, women continue to take on more childcare and household duties (Nomaguchi and Milkie 2003).

Burns, Schlozman, and Verba (2001) provide a more nuanced perspective on the gender differential in political engagement by suggesting that the gap results from the confluence of available resources, recruitment, and political or psychological orientations. For the first two components, women continue to lag behind men in the major predictive categories of political participation: “education, income, and occupational status” (Burns, Schlozman, and Verba 2001, 359). Psychologically, women also tend to have less interest, knowledge and perceived efficacy than men. Once these items are accounted for, the presence of children, whether or not a woman 
stays home with the children or possesses a full-time job did not significantly affect the gender gap in voting or other participatory acts (Burns, Schlozman, and Verba 2001). In further support of this hypothesis, High-Pippert (1999) found that traditional socio-economic status (SES) factors like income and education were more important predictors of voting than situational variables like the presence of children in the home. In addition, an individual's political interest and efficacy were strong enough to offset the political costs of caring for children.

Though the overall "gender gap" in political participation seems to have narrowed in recent years, there are still gender differences in the nature of political engagement and the effects of other factors. For example, low education more aversively affects voter turnout for women than men, but the voting gap disappears at high levels of education (Lewis-Beck et al. 2008). When accounting for political knowledge, women with high levels of knowledge are more likely than men to vote, sport a political button, and work on a campaign and just as likely to influence a vote, go to a political meeting, or donate to a political cause (Ondercin and Jones-White 2011). Low levels of knowledge, however, adversely and disproportionately affect participation for women, as compared to men, in these areas.

Similar to the entry of women into political office, "women hold themselves to a higher standard before engaging in political activities" (Ondercin and Jones-White 2011, 674). For the purposes of the current study, it is possible that women who bear more children because of a belief in traditional family structures feel knowledgeable on political issues and candidates that intersect with these beliefs. Indeed, women tend to be more knowledgeable and participate more in local school board elections (an area of politics that has been traditionally more open to women) than men (Burns, Schlozman, and Verba 2001), so it stands to reason that women could 
be mobilized more broadly around family issues in which they feel comfortable with their opinions.

Some of the studies of traditional methods of participation may miss women's political engagement in "loose, informal, more egalitarian, and local networks," such as interactions with other parents, voluntary organizations, and religious affiliations (Burns, Schlozman, and Verba 2001; Stolle and Micheletti 2006, 46). It is in these localized networks where women have the opportunity to build social capital as well as engage in political discussions that enable them to “develop fundamental tools of political understanding” that solidify social identity locally within groups and possibly to a corresponding broader, larger social group (Cramer Walsh 2004, 2;

Gidengil et al. 2006). Whether at church, with friends or in the home, religiously conservative women may be encountering consistent messages that promote traditional family structures and help them to identify with others who support their concerns, possibly in the political realm. The convergence of the social capital that is generated through children, family, and religion may then lead to increased political interest, knowledge, and participation.

\section{THE SOCIAL CAPITAL OF CHILDREN AND RELIGION}

The presence of children in the home does not have to serve as an obstacle to political engagement as they may provide avenues of social capital for their parents. Through school and extracurricular activities, children often involve their parents in social networks with other parents and the broader community (Offer and Schneider 2007; Sapiro 2006). In addition, involvement in religious communities, especially as it translates to building friendships in congregations, contributes to well being and the generation of social capital that can translate into civic engagement (Lim and Putnam 2010; Putnam 2000; Smidt et al. 2003; Verba, Schlozman, and Brady 1995; Wald, Kellstedt and Leege 1993) This involvement seems to be 
especially effective for those with strong religious identities or those that report the importance of religion in their lives (Lim and Putnam 2010). The importance of religion measure also has been linked to increased intended and actual fertility in women (Hayford and Morgan 2008), indicating that women with strong religious identities purposefully tend to have more children than their peers and may also be reaping the benefits of congregational as well as child-induced social networking. Generation of this social capital would serve as a "bonding" rather than "bridging” capital, as it would focus on building a common identity of traditional gender roles and the importance of preserving family values and morality (Cramer Walsh 2004; Everitt 2006; Klatch 1988; Putnam 2000).

If churches simultaneously promote childbearing and generate social networks, women in these networks may experience a "double effect" of social capital. In fact, religious institutions often use strategies to promote childbearing (Lehrer 2004; McQuillan 2004; Morgan 1996; Wilcox, Chaves, and Franz 2004), as some church leaders influence daily behavior of members through broadcasted norms and ensuing "sanctions ranging in format from guilt to damnation" (Lesthaeghe and Surkyn 1988, 13). Indeed, frequency of church attendance, regardless of denomination, is a strong predictor of an individual's preference for families of three or more children (Hayford and Morgan 2008; Lesthaeghe and Surkyn 1988).

Traditionally, most fertility studies involving religious influence have addressed the differences between Catholics and Protestants, as Catholics tended to have larger families; but currently, this gap is almost nonexistent due to later marriage by Catholics (resulting in fewer children) and larger families of Protestants who attend church frequently (Lehrer 2004; McQuillan 2004; Mosher, Williams and Johnson 1992). More recent studies focus on the fertility differentials between mainline and evangelical Protestants, mostly attributed to doctrinal 
differences of evangelicals espousing stronger pronatalist views (be fruitful and multiply) and an aversion to contraceptives and abortion (playing God) (Marcum 1981; McQuillan 2004). Hout, Greeley, and Wilde (2001) found that 76\% of conservative Protestant growth resulted from higher fertility and women beginning to bear children at younger ages, with women belonging to conservative denominations averaging close to one birth more than those associated with mainline Protestantism. The prevalence of conservative Protestant and Mormon churches also have been linked to local populations' fertility patterns, with more conservative US counties reporting higher marital fertility and lower age of initial childbearing (Lesthaeghe and Neidert 2006; Morrison 2009). These studies suggest that earlier age at first birth is the driving factor of higher overall fertility.

Religious influence on fertility and political behavior also varies by race in the United States, but the current study will focus on non-black Americans, following the lead of recent religion and fertility literature. As Morrison $(2009,105)$ notes, “African Americans maintain a unique set of patterns: higher total fertility, earlier age of parenting, higher nonmarital fertility, and lower marital fertility” that also may interact with religious affiliation differently than nonblacks. Furthermore, the theoretical basis of the current study is the political mobilization of the religious right around Republican platforms of family values and moral decay, which mostly have been limited to non-black evangelicals (Layman 2001; Wuthnow 1988).

\section{RALLY ROUND THE FAMILY}

Denominational affiliation and personal religious beliefs are associated with childbearing trends, but there also may be overarching movements that are simultaneously encouraging traditional family structures and associated political participation. In the 1980s two conservative, Christian Right organizations, the Moral Majority and the Christian Coalition, became socially 
and politically influential in evangelical Protestant denominations (Brooks 2002; Layman 2001; Wilcox 1992; Wuthnow 1988). Several other organizations, like Concerned Women for America and Phyllis Schlafly's Eagle Forum, were able to mobilize women because of the issue salience of matters relating to morality and family (Critchlow 2005; Klatch 1988). With the changing structure of the American family, including increases in divorce and single parenthood, conservative Protestants have reacted the "most forcefully and negatively" through promotions of pro-traditional-family literature and discourse (Brooks 2002; Lesthaeghe and Neidert 2006; Wilcox et al. 2004, 493). Many Christian Right organizations, like Focus on the Family, advocate heterosexual, married parent households, though they recently have shied away from explicitly teaching the necessity of stay-at-home mothers (Wilcox et al. 2004), or related issues of family size.

In this way, fertility, or at least its motivation and initial onset, seems to be splitting along similar religious lines that divide partisan loyalties (Cahn and Carbone 2010; Layman 2001; Wuthnow 1988). Early studies examining the link between religion and politics established the tendency for non-Southern Protestants to identify with the Republican Party and Catholics and Jews with the Democrats (Layman 2001; Wuthnow 1988). Before the 1980s, “evangelical Christians were a large, unattached constituency” (Layman 2001, 45), divided between those more concerned with the kingdom of God than earthly politics, those in the South reconsidering their traditional home in the Democratic Party, and those in lower classes tied to New Deal Democrats (Fowler, Hertzke, and Olson 1999). When the GOP began to incorporate elements of cultural conservatism into their platforms, leaders like Phyllis Schlafly could "translate conservative ideas to grassroots activists and motivate them to achieve political goals," thereby mobilizing evangelicals on issues of perceived moral decline (Critchlow 2005, 6; Fowler, 
Hertzke, and Olson 1999; Layman 2001; Wilcox 1992; Klatch 1988). With the majority of evangelicals identifying with the Republican Party and supporting its candidates in the 1980s, 1990s, and 2000s, they have become an important, consistent voting bloc for the GOP (Fowler et al. 1999; Layman 2001; Smidt et al. 2010; Wilcox 1992).

What is it about these beliefs and practices that may simultaneously influence families and politics? Following the restructuring hypothesis (Wuthnow 1988), Layman $(2001,66)$ divides individuals into two categories -- "traditionalists," which refers to individuals "with high levels of orthodoxy and commitment," and their opposites, “modernists” -- as a means to examine the political differences among religious Americans. These terms take into account what Layman (2001) and others consider the three important factors in the relationship between politics and religion: believing (personal theology), belonging or affiliation, and behaving (religious involvement). If we think in terms of religious influence on fertility, believing would refer to one's understanding of biblical instructions concerning childbearing. This could mean a complete adherence to something like the Quiverfull movement ${ }^{2}$ where one should not use birth control, family planning, or any other hindrance to reproduction or it could refer to one’s interpretation of a woman’s place in the home or society (Hagerty 2009; McQuillan 2004). Though the Quiverfull interpretation may seem extreme, beliefs of a woman's primary role as wife and mother would be considered more orthodox or traditionalist.

Behaving may be understood as either "ritual practice” or "private devotionalism” (Layman 2001, 57), and those with higher church participation tend to absorb more political guidance from others in their faith community (McQuillan 2004; Wald, Kellstedt, and Leege 1993). For example, if a pastor chooses to encourage the Bible's message to "be fruitful and multiply” (Hagerty 2009), a church member who attends regularly may be more likely to adopt 
this mindset. Furthermore, if fellow members are having larger families, regular attenders may be influenced by their peers (McQuillan 2004) as is the case for a Quiverfull family of 9 who attends an evangelical church where members average 8.5 children per household (Hagerty 2009).

The final factor of the religion-politics model encompasses the traditional understanding of religion's role in public life - belonging or religious affiliation. Though the levels of believing and behaving mediate the effects of belonging, there are still strong relationships between religious affiliation and political ideology and behavior. The fertility literature has identified differences in childbearing across faith traditions, but the effects have been weak in some cases (Hout, Greeley, and Wilde 2001; Mosher, Williams, and Johnson 1992) or based on geographic concentrations of faith traditions where fertility differences may be more attributable to earlier ages of first birth (Cahn and Carbone 2010; Lesthaeghe and Neidert 2006; Morrison 2009). Because higher fertility is associated with a woman's reported importance of religion in everyday life (Hayford and Morgan 2008), it may be more likely that individual believing and behaving could be more indicative of fertility choices over the singular measure of denominational affiliation. Higher levels of commitment and orthodoxy may lead to stronger gender role expectations that could be tied to both higher intended and actual fertility (Hayford and Morgan 2008) as well as political motivation on social issues tied to their religious beliefs (e.g. abortion, same-sex marriage).

The combination of children and religious community involvement may lead to a greater store of “'moral resources” that lead to increased cooperation among individuals” (Smidt et al. 2003, 153), which may translate into the generation of civic skills and eventual political involvement (Verba, Schlozman, and Brady 1995). Though the effects of church attendance or 
involvement may not directly influence political engagement (Smidt et al. 2003), if church teachings, personal beliefs, and elite political messages intersect, translation of religious social capital to political mobilization may be more likely (Cahn and Carbone 2010; Layman 2001). As Wuthnow $(1988,202)$ suggests, the overlap of morality and politics led evangelicals to think of their involvement in the public sphere as less political and more "a public stand on matters they knew to be morally mandated as part of scripture.” This convergence of family values, political debate, and social capital may have led to the emergence of conservative female political activists and their ability to convince rank-and-file conservative women that "only women's moral superiority could adequately confront the issues at hand” (Critchlow 2005; Klatch 1988; Rymph 2006, 5). That is, mothers who care about traditional family values because of their religious beliefs may possess the social capital and knowledge (Ondercin and Smith-Jones 2011), necessary to overcome the fact that childrearing may serve as a barrier to political engagement because it is for their children and their families that they choose to be politically involved.

\section{HYPOTHESES AND METHODS}

The hypotheses listed below were tested using the 2004 National Rolling Cross-Section of the National Annenberg Election Survey (NAES) ${ }^{3}$, as it provided measures of the key variables (see Appendix A). Regarding an individual's family size, the NAES asks for the number of children under the age of 18 living in the household. This could include grandchildren, foster children, adopted children, or any other children unrelated to the respondent, but it would not include deceased children or those over the age of 18 who have moved away. Because of this, many NAES respondents older than the age of 65 reported 0 children under 18 living in their households, ${ }^{4}$ with 0.69 children as the average number of children for all non-black respondents. The average age of this sample is 48 years-old, with a mean income falling between $\$ 35,000$ and 
$\$ 50,000$, and mean educational attainment is some college or a two-year degree. Political ideology is included because the effects of children and religiosity on social capital are expected to be dependent on ideology, as more conservative women will experience this effect. Ideology was measured on a five-point scale, from very liberal (1) to very conservative (5), with a mean of 3.2. As mentioned earlier, this study will focus on non-blacks, and the NAES race variable was recoded to a dichotomous variable of black and non-black, with the Black cases dropped from the analyses.

For the religious traditionalist measurement, frequency of church attendance and having a born-again experience were combined into one variable. Individuals who were not born again were coded 0 , and those that were born again received the score associated with frequency of attendance to account for their level of commitment -1 through 5 . Sixty percent of the non-black sample do not consider themselves born again, thereby scoring a 0 on this measure, and $24 \%$ are born again and attend church at least once a week, with a value of 4 or 5 on the measure. Though not perfectly correlated with denomination, these items reflect religious belief and behavior and are strong predictors of evangelical Protestant affiliation (Layman 2001; Smith 1990; Steensland et al. 2000). Unfortunately, the NAES affiliation measure only includes the categories Protestant, Catholic, Jewish, Mormon, Orthodox, Muslim, Other, No denomination, and atheist or agnostic, so a comparison across traditionalist and modernist Protestant denominations would be impossible. There is a positive relationship between religious traditionalism and political ideology $(r=0.30, p<0.001)$, and the relationship is similar for men and women.

H1: Religious traditionalists are bearing more children than their peers. Previous research has focused on county-level data (Lesthaeghe and Neidert 2006; Morrison 2009) or strictly denominational affiliation (Hout, Greely, and Wilde 2001; Mosher et al. 1992) when exploring 
fertility differences among American Christians. To test the hypothesis that the beliefs and messages that may mobilize conservative women politically are encouraging higher fertility rates, it is important to determine whether religious traditionalists are having more children than their peers, which is a slightly different measure than previously used in the literature.

There are positive but weak, relationships between an individual's number of children in the home and religious traditionalism $(r=0.03, p<0.001)$ and ideology $(r=0.06, p<0.001)$. To account for demographic variables that directly influence family size, total children was regressed on traditionalism, ideology, age, marital status, education, and income. As displayed in Table 1, tobit analysis was used as the dependent variable "has a number of its values clustered at a limiting value” (McDonald and Moffitt 1980, 318), with 65\% of the non-black sample reporting 0 children. Tobit left-censors the dependent variable, with an assumption that not everyone in the "zero" category can be treated the same. In addition, the coefficients generated through the tobit method provide more a intuitive understanding than other count variable methods. When compared to an ordinary least squares (OLS) regression model with the same parameters, the coefficients increase for age and marriage and change directions on income. For example, when accounting for those whose children have left home and are not measured (censored in the 0 category), age becomes a stronger predictor of family size as growing older gives individuals more time to have more children. Importantly, the key predictors were significant and in the hypothesized direction in the OLS and tobit models.

With each one-point increase on the traditionalism score (essentially being born again and increased church attendance), an individual's number of children in the home increases by 0.03 ( $\mathrm{p}<0.001$ ), holding all other variables constant. A similar relationship emerges for political ideology, as a one-point increase in conservatism results in an 0.11-increase in the number of 
children, accounting for all the other variables. These relationships are consistent for men and women and support the first hypothesis.

$<$ Insert Table 1 About Here>

\section{Political Participation}

H2: Each additional child will more negatively affect the political behavior of women over men.

H3: The negative relationship between childbearing and political behavior is moderated by religious traditionalism and political ideology.

If individuals who frequently attend church and are born again tend to bear more children, the next step is to test whether children combined with religiosity translates into social capital that helps these individuals overcome barriers to political participation. Since socioeconomic status and individual interest in politics are consistent and strong predictors of voting behavior (Berinsky 2005; Verba, Schlozman, and Brady 1995), we would not expect one’s number of children or its interaction with traditionalism or ideology to have much effect on voting as a dependent variable. Because the NAES was administered at different intervals throughout the 2004 presidential campaign and election, the most consistent and largest sample size question referred to the respondent's voting behavior in the 2000 presidential election. See Appendix A for wording on the question and coding specifics.

The bivariate relationship between voting and total number of children in the home is negative for women $(r=-0.14, p<0.001)$ and men $(r=-0.05, p<0.001)$. A logistic regression was performed on the dichotomous dependent variable of voting for the full population and then split by gender, with number of children, traditionalism, ideology and the interaction terms as key variables. Results are displayed in Table 2. Because of the difficulty in interpreting logged 
odds, the logit coefficients were transformed into odds ratios. By subtracting one from the odds ratio, we can determine the odds a person will vote when the independent variable is increased by one unit and all others are held constant. Contrary to the second hypothesis, the odds of voting decrease for each additional child in the home for women and men, though the relationship only reaches traditional levels of statistical significance in the model with both genders. Increased traditionalism and conservative ideology are associated with increased odds of voting, with a 1-point increase in religious traditionalism resulting in a $6 \%$ increase in the odds of voting for women and a 9\% increase for men, holding all other variables constant. There is a stronger relationship between ideology and voting for men over women, as a 1-point increase in conservatism results in a $21 \%$-increase $(\mathrm{p}<0.001)$ in odds a man will vote, compared to a 5\%increase $(\mathrm{p}<0.05)$ for women.

There is no relationship between the interaction of children and traditionalism and the odds of voting. At the very least, we can conclude that if one increases traditionalism with each additional child, the odds are no more or less likely that the individual will vote more than his or her peers. In essence, the interaction neutralizes the negative relationship between number of children and voting. Interestingly, the interaction between number of children and political ideology achieves statistical significance, as increases in conservatism among those with the same number of children results in a 3\% increase in the odds that individual voted in the 2000 election, holding all other variables constant. These findings partially support the third hypothesis that political ideology moderates the negative effects of children on political behavior.

$<$ Insert Table 2 About Here $>$ 
Voting is just one form of political engagement and may be the bluntest measure as the choice of political candidates may not translate directly to the intersection of children, religion, social capital, and political issues related to family. Political discussions with friends and family may be more applicable to conservative Christians who are issue-driven with policies that tend to coincide with religious beliefs and be spoken about in their social networks. Specifically, preferences of traditional gender roles and the importance of family may be discussed in both religious and political terms, joining the social capital forces of children and religiosity to generate political interest, discussion, and increased knowledge that all can lead to feeling more prepared to participate (Gidengil et al. 2006; Ondercin and Smith-Jones 2011). The NAES asks respondents how many days in the last week they discussed politics with friends or family, with scores ranging from zero to seven. The overall mean for non-blacks is 2.98 days a week, with a significant mean difference between women (2.92) and men (3.06). The number of children in the home and the frequency of political discussion are negatively correlated, though weakly, for women $(\mathrm{r}=-0.07, \mathrm{p}<0.001)$ and men $(\mathrm{r}=-0.03, \mathrm{p}<0.001)$.

Number of days of political discussion was regressed on total children, traditionalism, ideology, and the interaction terms, along with age, marital status, education, and income, with the results shown in Table 3. The negative relationship between frequency of political discussion and number of children in the home remains statistically significant, holding all other variables constant, for women $(\beta=-0.12, \mathrm{p}<0.001)$ and men $(\beta=-0.10, \mathrm{p}<0.001)$, supporting the hypothesis that women are more affected than men by the presence of children in the home. There is a weak but positive relationship between traditionalism and political discussion for men ( $\beta=0.01, \mathrm{p}<0.10$ ) and no relationship for women, and ideology is negatively related to 
discussion for women $(\beta=-0.04, \mathrm{p}<0.001)$. As women decrease ideological conservatism, their discussion increases - which is the opposite effect from voting. When combined into interaction terms, significant relationships emerge in the hypothesized direction. For individuals with the same number of children, a 1-point increase in traditionalism results in a 0.02-day increase ( $\mathrm{p}<$ 0.001) in frequency of political discussion, holding all other variables constant. This relationship holds for men ( $\mathrm{B}=0.03, \mathrm{p}<0.01)$ but drops in significance for women $(\mathrm{B}=0.01, \mathrm{p}<0.10)$. The interaction between ideology and number of children is significant for all models, regardless of gender. Holding all other variables constant, a 1-point increase in ideology, among those with the same number of children, is associated with a 0.04-day increase $(\mathrm{p}<0.001)$ in frequency of political discussion. Though the number of children in the home decreases political discussion, this effect is reversed when accounting for ideology and religiosity, with more conservative and more traditionalist individuals discussing politics more than their peers with the same number of children.

\section{$<$ Insert Table 3 About Here>}

A third test of the hypothesis was performed with an OLS regression on the extent to which an individual follows politics - most times (4), sometimes (3), now and then (2), or hardly at all, with an overall mean of 3.11 (1). There is a weak, bivariate relationship between following politics and number of children in the home $(r=-0.09, \mathrm{p}<0.001)$, with a stronger relationship for women $(r=-0.15, \mathrm{p}<0.001)$ than men $(\mathrm{r}=-0.07, \mathrm{p}<0.001)$. Table 3 displays the results of following politics regressed on total children, traditionalism, ideology, the interaction terms, and demographic variables. Consistent with the previous tests of political engagement, number of children is negatively related to an individual's tendency to follow politics, with women ( $\beta=$ - 
$0.10, \mathrm{p}<0.001)$ slightly more affected than men $(\beta=-0.07, \mathrm{p}<0.01)$. Religiosity is significantly related to following politics for women, as a 1-point increase in traditionalism results in a $0.02-$ point increase in political interest $(\mathrm{p}<0.001)$, holding all other variable constant. Religiosity is not significant for men, but ideology is related to following politics, as a 1-point increase in conservatism results in a 0.05 -increase in interest $(\mathrm{p}<0.001)$. Ideology was not significant for women, but its interaction with number of children results in a positive relationship with the dependent variable. Among women with the same number of children, a 1-point increase in conservatism results in a 0.02-increase in following politics $(\mathrm{p}<0.001)$, holding all other variables constant. This interaction was not significant for men, and the interaction between traditionalism and number of children was only weakly related to following politics for men (p < 0.10, and not at all related for women.)

<Insert Table 4 About Here>

In sum, even when accounting for the powerful relationships between forms of political participation and age, income, education, and marital status, the key variables in this study significantly contributed to these models. The number of children in the home had consistent, negative effects on individuals’ political engagement, and though this relationship held for men and women, women were slightly more affected. The interactions between number of children and traditionalism either neutralized the negative effects of children (following politics and voting for men and women and political discussion for women) or reversed the relationship (discussing politics for men). Interestingly, the interaction effects were stronger for ideology and number of children as it resulted in an increase in voting, discussing politics with friends and family, and following politics for women and voting and discussing politics for men. This 
generates questions of causality concerning whether religiosity, as it is measured here, is driving political and fertility behavior or if political ideology is the influential force.

To test a possible three-way interaction between ideology, religiosity, and children, the sample was split by ideology - conservatives, moderates, and liberals - and the participation models performed again. ${ }^{5}$ Regarding political discussion for men (results not shown), there is a negative relationship with number of children, but this is reversed for the interaction between religiosity and children such that an increase in traditionalism results in more political discussion among those with the same number of children, holding all other variables constant. This relationship between the interaction term and discussion holds weakly for liberals $(\beta=0.03, \mathrm{p}<$ $0.10)$ and significantly for moderates $(\beta=0.04, \mathrm{p}<0.01)$ and conservatives $(\beta=0.03, \mathrm{p}<0.05)$. Among men with similar political ideology, increased traditionalism is associated with increased political discussion, with the same number of children present in the home. The results shift for women, as displayed in Table 5.

\section{$<$ Insert Table 5 about Here>}

For liberal and moderate women, the number of children in the home and traditionalism are negatively associated with political discussion. As one's number of children increases, these women are less likely to discuss politics with friends and family than their ideological peers, holding all other variables constant. Increases in religious traditionalism among liberals and moderates also are less likely to discuss politics, but when combined with children in an interaction term, this affect reverses or at least neutralizes the negative effects (liberals: $\beta=0.03$, $\mathrm{p}<0.10$; moderates: $\beta=0.02, \mathrm{p}<0.10$ ). Among their ideological peers with the same number of children, increases in religious traditionalism results in more political discussion for liberals and 
moderates. For ideological conservatives, children still negatively affect discussion $(\beta=-0.05, \mathrm{p}$ $<0.01)$, traditionalism increases discussion $(\beta=0.04, \mathrm{p}<0.01)$, but the interaction between children and traditionalism is not significant $(\beta=0.00, \mathrm{p}=0.789)$.

Because ideology and its interaction with number of children were stronger predictors than religiosity of women's political engagement, the latter results indicate a point of marginal returns - that is, when a woman is already ideologically conservative, increases in church attendance/being born again (traditionalism) and number of children do not form additional social capital. As was demonstrated in the original discussion model in Table 3, increases in ideology make the difference for those with the same number of children, with traditionalism and the other variables held constant.

To examine this relationship from another angle, women in the sample were grouped by level of religious traditionalism where low = those who are not born again; medium=born again and attend church between never and a few times a month; and high = born again and attend weekly or more. Similar effects emerge as the interaction between children and ideology is significant only among women low in traditionalism. That is, though children and ideological conservatism have negative effects on political discussion, the interaction indicates that among non-born again women with the same number of children, increases in political conservatism result in discussing politics more days of the week $(\beta=0.11, \mathrm{p}<0.001)$. The traditionalist measure is somewhat blunt because it treats all non-born again women the same, regardless of frequency of church attendance. Among women who are not born again, there is a positive, bivariate relationship between ideology and church attendance $(r=0.18, p<0.001)$ so increases in conservatism interacting with number of children on discussion may be representing social 
capital built through church attendance. The bottom line is that it appears conservatism, whether ideological or religious, may represent an underlying motivation for women - and men -- to choose larger family sizes and remain politically active, as compared to their peers with the same number of children.

\section{CONCLUSION}

In this sample, political conservatism and religious traditionalism are positively associated with increases in the number of children in the home. The number of children present in the home also is negatively associated with political participation, but these effects are neutralized or even reversed when accounting for religiosity and ideology. Children alone are not serving as political capital, as increasing numbers result in decreased political behavior. Traditionalism, measured by religious belief and church attendance, appears to confirm earlier studies of the influence of religious identity and involvement in building social capital for voting and following politics (Lim and Putnam 2010; Smidt et al. 2003). Children only emerge as a form of social capital when combined with religious traditionalism or political conservatism, and though the effect is not universal across the dependent variables in this study, this pattern emerges for both men and women. Former studies have suggested that marriage and children have better served men over women in regards to political engagement (Burns, Schlozman, and Verba 2001; Sapiro 2006), but in the case of religious and/or political conservatives, women also may be converting their families and accompanying social identities into social capital. Burns, Schlozman, and Verba (2001, 321) suggest that though their data do not demonstrate adverse, independent effects for marriage and children on participation, these family structures seem to be "channeling individuals into secondary institutions," such as religion and the workforce for men, that do 
influence political behavior. The current study suggests religion, children, and the accompanying social identity when the two converge could be "channeling" women in the same way.

These findings reaffirm the success of grassroots conservative movements in mobilizing two formerly low-participating groups - evangelicals and women - around a set of values central to their worldview. In 2004 NAES, both men and women reported participating less with each additional child, but the presence of children and conservative preferences generated more engagement than their peers, indicating another form of social capital may influence participation: when personal identity coincides with political issue salience. Scholars have long recognized that the religious right were mobilized on family-related policy (Layman 2001; Wuthnow 1988), but the current study provides additional understanding of why this mobilization may have occurred and continues to be the case. Taking a "moral stand" (Wuthnow 1988, 202) through political engagement around these issues could be a result of social identities formed through informal conversations encountered by frequent church attendance or association with other like-minded individuals. These discussions, perhaps about abortion or gay marriage, may increase individuals' knowledge about issues and possible candidates as well as solidifying social identities that fit into a broader group (Cramer Walsh 2004). If women who would typically exhibit less political interest and participation are able to increase their knowledge and sense of efficacy (Ondercin and Smith-Jones 2011; Burns, Schlozman, and Verba 2001) in knowing they belong to a broader movement (e.g. affiliation with the Moral Majority), the participation disparity disappears, as compared to men and women with fewer or no children. In this way, children and political and religious conservatism build social capital that may generate the knowledge and efficacy needed for women to feel adequately prepared for the political realm (Ondercin and Smith-Jones 2011; Burns, Schlozman, and Verba 2001). As Everitt (2006, 274) 
suggests, "social capital is more important to the political orientations of women who see their lives based in the private sphere of home and the family than it is to those women with more egalitarian gender-role beliefs who are already actively involved in the labor force.” The latter women may be acquiring the resources, recruitment, and psychological orientations necessary for political involvement more similarly to men (Burns, Schlozman, and Verba 2001), but the former may rely more upon the informal conversations and lifestyle or religious networks to provide them with the tools necessary for political involvement.

The relationships between religiosity, children, and political engagement are less clear for liberal women. When there appears to be a cross-pressure to what might be considered a typical liberal identity, such as increased religious traditionalism or an increase in the number of children, political discussion decreases. It is possible that a political liberal who is born again and frequently attends church and/or has a large family may not discuss politics with those around them because they may be in social networks of conservatives (who agree with them religiously or share the commonality of children but politically disagree) or other liberals (who agree politically but disagree religiously and may not be supportive of large families). But the interaction between religious traditionalism and number of children has a small positive effect on discussion for liberals, suggesting that the shared identity of conservative religiosity and increases in family size may provide more avenues for liberals to engage in political discussion. There are other possible explanations, but further research could uncover how the convergence of gender, family life, religion, and ideology influences social networks to either promote or discourage political discussion and engagement (Huckfeldt, Johnson and Sprague 2004; Mutz 2006). Women, mothers, religious individuals, and ideologues cannot be treated as monolithic groups in their approach to politics. Understanding how various social identities--gender, race, 
religion, social class—and their interactions within individuals and groups impact political engagement may continue to illuminate existing disparities and possible barriers to democratic participation and a better represented citizenry. 


\section{APPENDIX A: NATIONAL ANNENBERG ELECTION STUDY VARIABLES}

Children: How many children under age 18 now live in your house or apartment? Measure: 0 through 8; 9 or more.

Ideology: Generally speaking, would you describe your political views as very conservative (5), conservative (4), moderate (3), liberal (2), or very liberal (1)?

Vote: Did you vote in the 2000 presidential election when George W. Bush ran against Al Gore? If yes: did you vote for George W. Bush, the Republican; Al Gore, the Democrat; Pat Buchanan of the Reform Party; Ralph Nader of the Green Party; or someone else? Measure: 1=Yes, voted for Bush, Gore, Buchanan, Nader or someone else; $0=$ Did not vote.

Political Discussion: How many days in the past week did you discuss politics with your family or friends? Measure: 0-7

Follow Politics: Some people seem to follow what is going on in government and public affairs most of the time, whether there is an election or not. Others are not that interested, or are interested in other things. Would you say you follow what is going on in government and public affairs most of the time, some of the time, only now and then, or hardly at all?

Church Attendance: How often do you attend religious services, apart from special events like weddings or funerals - more than once a week, once a week, once or twice a month, a few times a year, or never? $1=$ Never; $2=A$ few times a year; $3=$ Once or twice a month; $4=$ Once a week; $5=$ More than once a week.

Born Again: Do you consider yourself an evangelical or born-again Christian? Measure: 1=Yes; $0=$ No. 


\section{ACKNOWLEDGEMENTS}

An earlier version of this paper was presented at the 2010 Annual Meeting of the Midwest

Political Science Association, Chicago. The author wishes to thank Michael Wagner, Sarah

Michaels, Kevin Smith, and members of the University of Nebraska Lincoln Political Behavior

Working Group for their helpful reviews and feedback as well as Heidi Hartmann, Carol HardyFanta, and the anonymous reviewers for their valuable suggestions.

\section{REFERENCES}

Berinsky, Adam J. 2005. “The Perverse Consequences of Electoral Reform in the United States.” American Politics Research 33(4): 471-491.

Brooks, Clem. 2002. "Religious Influence and the Politics of Family Decline Concern:

Trends, Sources, and U.S. Political Behavior.” American Sociological Review 67(2): 191211.

Burns, Nancy, Kay Lehman Schlozman, and Sidney Verba. 2001. The Private Roots of Public Action: Gender, Equality, and Political Participation. Cambridge, MA: Harvard University Press.

Cahn, Naomi, and June Carbone. 2010. Red Families v. Blue Families: Legal Polarization and the Creation of Culture. New York: Oxford University Press.

Campbell, Angus, Philip E. Converse, Warren E. Miller, and Donald E. Stokes. 1960.

The American Voter. New York: Wiley.

Cramer Walsh, Katherine. 2004. Talking About Politics: Informal Groups and Social Identity in American Life. Chicago, IL: The University of Chicago Press.

Critchlow, Donald T. 2005. Phyllis Schlafly and Grassroots Conservatism: A Women’s 
Crusade. Princeton: Princeton University Press.

Everitt, Joanna. 2006. “Gender-Role Orientations and the Conversion of Social Capital.” In Gender and Social Capital. eds. Brenda O’Neill and Elisabeth Gidengil. New York: Routledge, 273-292.

Fowler, Robert Booth, Allen D. Hertzke, and Laura R. Olson. 1999. Religion and Politics in America: Faith, Culture, and Strategic Choices. $2^{\text {nd }}$ edition. Boulder, CO: Westview Press.

Gidengil, Elisabeth, Brenda O’Neill and Lisa Young. 2010. “Her Mother’s Daughter? The Influence of Childhood Socialization on Women’s Political Engagement.” Journal of Women, Politics \& Policy 31: 334-335.

Gidengil, Elisabeth, Elizabeth Goodyear-Grant, Neil Nevitte, and Andre Blais. 2006. “Gender, Knowledge, and Social Capital.” In Gender and Social Capital. eds. Brenda O’Neill and Elisabeth Gidengil. New York: Routledge, 241-272.

Hagerty, Barbara Bradley. March 26, 2009. “In Quiverfull Movement, Birth Control is Shunned.” NPR. <www.npr.org> (March 26, 2009).

Hayford, Sarah R., and S. Philip Morgan. 2008. "Religiosity and Fertility in the United States: The Role of Fertility Intentions.” Social Forces 86(3): 1163-1188.

High-Pippert, Angela. 1999. The Situational Explanation Revisited: Gender, Work, Family, and Political Participation. PhD Dissertation. University of NebraskaLincoln.

Hout, Michael, Andrew Greeley, and Melissa J. Wilde. 2001. “The Demographic Imperative in Religious Change in the United States.” The American Journal of Sociology 107(2): 468-500. 
Huckfeldt, Robert, Paul E. Johnson, and John Sprague. 2004. Political Disagreement: The Survival of Diverse Opinions within Communication Networks. New York: Cambridge University Press.

Klatch, Rebecca. 1988. “Coalition and Conflict Among Women of the New Right.” Signs 13(4): 671-694.

Layman, Geoffrey. 2001. The Great Divide: Religious and Cultural Conflict in American Party Politics. New York: Columbia University Press.

Lehrer, Evelyn L. 2004. "Religion as a Determinant of Economic and Demographic Behavior in the United States.” Population and Development Review 30(4): 707-726.

Lesthaeghe, Ron and Lisa Neidert. 2006. "The Second Demographic Transition in the United States: Exception or Textbook Example?” Population and Development Review 32(4): 669-698.

Lesthaeghe, Ron and Johan Surkyn. 1988. "Cultural Dynamics and Economic Theories of Fertility Change.” Population and Development Review 14: 1-45.

Lewis-Beck, Michael S., William G. Jacoby, Helmut Norpoth, and Herbert E. Weisberg. 2008. The American Voter Revisited. Ann Arbor: The University of Michigan Press.

Lim, Chaeyoon, and Robert D. Putnam. 2010. “Religion, Social Networks, and Life Satisfaction.” American Sociological Review 75: 914-933.

Marcum, John P. 1981. “Explaining Fertility Differences among U.S. Protestants.” Social Forces 60(2): 532-543.

McDonald, John F., and Robert A. Moffitt. 1980. "The Uses of Tobit Analysis.” The Review of Economics and Statistics 62(2): 318-321.

McQuillan, Kevin. 2004. “When Does Religion Influence Fertility?” Population and 
Development Review 30(1): 25-56.

Morgan, S. Philip. 1996. “Characteristic Features of Modern American Fertility.”

Population and Development Review 22: 19-63.

Morrison, Emory. 2009. “Conservative Churches and Fertility Innovation: A Cultural-

Ecological Approach to the Second Demographic Transition Among Nonblacks in the

United States.” Journal for the Scientific Study of Religion 48(1): 103-120.

Mosher, William D., Linda B. Williams, and David P. Johnson. 1992. "Religion and

Fertility in the United States: New Patterns.” Demography 29(2): 199-214.

Mutz, Diana, 2006. Hearing the Other Side. Cambridge University Press.

Nomaguchi, Kei M., and Melissa A. Milkie. 2003. “Costs and Rewards of Children: The Effects of Becoming a Parent on Adults’ Lives.” Journal of Marriage and Family 65: 356-374.

Offer, Shira, and Barbara Schneider. 2007. "Children’s Role in Generating Social Capital.” Social Forces 85(3): 1125-1142.

Ondercin, Heather L., and Daniel Jones-White. 2011 “Gender Jeopardy: What is the Impact of Gender Differences in Political Knowledge and Political Participation?” Social Science Quarterly 92(3): 674-694.

Putnam, Robert D. 2000. Bowling Alone: The Collapse and Revival of American Community. New York, NY: Simon \& Schuster.

Rymph, Catherine E. 2006. Republican Women: Feminism and Conservatism from Suffrage Through the Rise of the New Right. Chapel Hill: University of North Carolina Press.

Sapiro, Virginia. 2006. “Gender, Social Capital, and Politics.” In Gender and Social Capital. eds. Brenda O’Neill and Elisabeth Gidengil. New York: Routledge, 151-183. 
Smidt, Corwin E., Kevin R. den Dulk, Bryan T. Froehle, James M. Penning, Stephen V. Monsma, and Douglas L. Koopman. 2010. The Disappearing God Gap? Religion in the 2008 Presidential Election. Oxford: Oxford University Press.

Smidt, Corwin, John Green, James Guth, and Lyman Kellstedt. 2003. "Religious Involvement, Social Capital, and Political Engagement: A Comparison of the United States and Canada.” In Religion as Social Capital: Producing the Common Good. ed. Corwin Smidt. Waco, TX: Baylor University Press, 153-170.

Smith, Tom W. 1990. “Classifying Protestant Denominations.” Review of Religious Research 31(3): 225-245.

Steensland, Brian, Jerry Z. Park, Mark D. Rengerus, Lynn D. Robinson, W. Bradford Wilcox, and Robert D. Woodberry. 2000. “The Measure of American Religion: Toward Improving the State of the Art.” Social Forces 79(1): 291-324.

Stolle, Dietlind, and Michele Micheletti. 2006. “The Gender Gap Reversed: Political Consumerism as a Women-Friendly Form of Civic and Political Engagement.” In Gender and Social Capital. Brenda O’Neill and Elisabeth Gidengil, eds. New York: Routledge, 4572.

Verba, Sidney, Kay Lehman Schlozman, and Henry E. Brady. 1995. Voice and Equality: Civic Voluntarism in American Politics. Cambridge: Harvard University Press.

Wald, Kenneth D., Lyman A. Kellstedt, and David C. Leege. 1993. “Church Involvement and Political Behavior.” In Rediscovering the Religious Factor in American Politics. eds.David C. Leege, and Lyman A. Kellstedt. Armonk, NY: M.E. Sharpe, 121-138.

Wilcox, Clyde. 1992. God's Warriors: The Christian Right in Twentieth-Century America. Baltimore: The Johns Hopkins University Press. 
Wilcox, W. Bradford, Mark Chaves, and David Franz. 2004. "Focused on the Family:

Religious Traditions, Family Discourse, and Pastoral Practice.” Journal for the Scientific Study of Religion 43(4): 491-504.

Wuthnow, Robert. 1988. The Restructuring of American Religions: Society and Faith Since World War II. Princeton, NJ: Princeton University Press. 
Table 1: Tobit Results of Total Number of Children on Religious Traditionalism and Ideology

\begin{tabular}{|c|c|c|c|}
\hline & \multicolumn{3}{|c|}{ National Annenberg Election Survey } \\
\hline & $\begin{array}{c}\text { Women and Men } \\
\text { Coef. }\end{array}$ & $\begin{array}{c}\text { Women } \\
\text { Coef. }\end{array}$ & $\begin{array}{l}\text { Men } \\
\text { Coef. }\end{array}$ \\
\hline Traditionalism & $\begin{array}{c}0.03^{* * *} \\
(0.01)\end{array}$ & $\begin{array}{c}0.02 * * \\
(0.01)\end{array}$ & $\begin{array}{c}0.03 * * * \\
(0.01)\end{array}$ \\
\hline Ideology & $\begin{array}{c}0.11^{* * *} \\
(0.01)\end{array}$ & $\begin{array}{c}0.13^{* * * *} \\
(0.02)\end{array}$ & $\begin{array}{c}0.11^{* * * *} \\
(0.02)\end{array}$ \\
\hline Age & $\begin{array}{c}-0.09 * * * \\
(0.00)\end{array}$ & $\begin{array}{c}-0.10^{* * * *} \\
(0.00)\end{array}$ & $\begin{array}{c}-0.09 * * * \\
(0.00)\end{array}$ \\
\hline Married & $\begin{array}{c}1.58^{* * *} \\
(0.03)\end{array}$ & $\begin{array}{c}1.09 * * * \\
(0.03)\end{array}$ & $\begin{array}{c}2.22 * * * \\
(0.04)\end{array}$ \\
\hline Education & $\begin{array}{c}-0.04^{* * *} \\
(0.00)\end{array}$ & $\begin{array}{c}-0.06^{* * *} \\
(0.01)\end{array}$ & $\begin{array}{c}-0.05^{* * *} \\
(0.01)\end{array}$ \\
\hline Income & $\begin{array}{c}0.05^{* * *} \\
(0.01)\end{array}$ & $\begin{array}{c}0.05^{* * *} \\
(0.01)\end{array}$ & $\begin{array}{c}0.10^{* * *} \\
(0.01)\end{array}$ \\
\hline Constant & $\begin{array}{c}2.19 * * * \\
(0.06)\end{array}$ & $\begin{array}{c}2.93 * * * \\
(0.08)\end{array}$ & $\begin{array}{c}1.22 * * * \\
(0.09)\end{array}$ \\
\hline $\mathrm{N}$ & 55,534 & 30,691 & 24,843 \\
\hline Chi-square & $18,623 * * *$ & $11,443.04 * * *$ & $8,003.44^{* * *}$ \\
\hline Log-likelihood & $-59,281.38$ & $-32,361.90$ & $-26,506.32$ \\
\hline $\begin{array}{l}\text { Left-censored } \\
\text { observations at } \\
\text { children } \leq 0\end{array}$ & 34,712 & 19,090 & 15,622 \\
\hline
\end{tabular}

Notes: ${ }^{*} \mathrm{p}<0.05 ;{ }^{* *} \mathrm{p}<0.01 ;{ }^{* * *} \mathrm{p}<0.001 ; \dagger<0.10$ (two-tailed tests); standard errors in parentheses. 
Table 2: Logistic Regression Results of Voting on Number of Children, Religious Traditionalism and Ideology

\begin{tabular}{|c|c|c|c|c|c|c|}
\hline & \multicolumn{6}{|c|}{ National Annenberg Election Survey } \\
\hline & \multicolumn{2}{|c|}{ Women and Men } & \multicolumn{2}{|c|}{ Women } & \multicolumn{2}{|c|}{ Men } \\
\hline & Coef. & Odds & Coef. & Odds & Coef. & Odds \\
\hline Children & $\begin{array}{l}-0.09 * \\
(0.04)\end{array}$ & $-8 \%$ & $\begin{array}{l}-0.09 \dagger \\
(0.05)\end{array}$ & $-8 \%$ & $\begin{array}{l}-0.10 \dagger \\
(0.06)\end{array}$ & $-10 \%$ \\
\hline Traditionalism & $\begin{array}{c}0.07 * * * \\
(0.01)\end{array}$ & $13 \%$ & $\begin{array}{c}0.05^{* * *} \\
(0.01)\end{array}$ & $6 \%$ & $\begin{array}{c}0.09 * * * \\
(0.01)\end{array}$ & $9 \%$ \\
\hline Ideology & $\begin{array}{c}0.11^{* * *} \\
(0.02)\end{array}$ & $12 \%$ & $\begin{array}{l}0.05^{*} \\
(0.02)\end{array}$ & $5 \%$ & $\begin{array}{c}0.19 * * * \\
(0.02)\end{array}$ & $21 \%$ \\
\hline Tradition x Child & $\begin{array}{l}-0.001 \\
(0.01)\end{array}$ & $0 \%$ & $\begin{array}{c}0.00 \\
(0.01)\end{array}$ & $0 \%$ & $\begin{array}{c}-0.01 \\
(0.01)\end{array}$ & $10 \%$ \\
\hline Ideology x Child & $\begin{array}{c}0.03 * * \\
(0.01)\end{array}$ & $3 \%$ & $\begin{array}{l}0.03 * \\
(0.02)\end{array}$ & $3 \%$ & $\begin{array}{c}0.04 * \\
(0.02)\end{array}$ & $10 /$ \\
\hline Age & $\begin{array}{c}0.06 * * * \\
(0.00)\end{array}$ & $6 \%$ & $\begin{array}{c}0.07^{* * *} \\
(0.00)\end{array}$ & $7 \%$ & $\begin{array}{c}0.06 * * * \\
(0.00)\end{array}$ & $6 \%$ \\
\hline Married & $\begin{array}{c}0.26 * * * \\
(0.03)\end{array}$ & $30 \%$ & $\begin{array}{c}0.27^{* * *} \\
(0.04)\end{array}$ & $31 \%$ & $\begin{array}{c}0.26 * * * \\
(0.04)\end{array}$ & $32 \%$ \\
\hline Education & $\begin{array}{c}0.30 * * * \\
(0.01)\end{array}$ & $35 \%$ & $\begin{array}{c}0.32 * * * \\
(0.01)\end{array}$ & $38 \%$ & $\begin{array}{c}0.28 * * * \\
(0.01)\end{array}$ & $30 \%$ \\
\hline Income & $\begin{array}{c}0.20 * * * \\
(0.01)\end{array}$ & $22 \%$ & $\begin{array}{c}0.22 * * * \\
(0.01)\end{array}$ & $24 \%$ & $\begin{array}{c}0.19 * * * \\
(0.01)\end{array}$ & $32 \%$ \\
\hline Constant & $\begin{array}{c}-4.36^{* * *} \\
(0.08)\end{array}$ & & $\begin{array}{c}-4.46^{* * * *} \\
(0.11)\end{array}$ & & $\begin{array}{c}-4.30 * * * \\
(0.12)\end{array}$ & \\
\hline $\begin{array}{l}\text { Pseudo } \mathbf{R}^{2} \\
\mathbf{N}\end{array}$ & \multicolumn{2}{|c|}{0.22} & \multicolumn{2}{|c|}{0.23} & \multicolumn{2}{|c|}{0.21} \\
\hline
\end{tabular}

Notes: ${ }^{*} \mathrm{p}<0.05 ;{ }^{* *} \mathrm{p}<0.01 ; * * * \mathrm{p}<0.001 ; \dagger<0.10$ (two-tailed tests); standard errors in parentheses 
Table 3: Results from OLS Regression of Discussing Politics with Friends or Family on Number of Children, Religious Traditionalism, and Political Ideology

\begin{tabular}{|c|c|c|c|c|c|c|c|c|c|}
\hline & \multicolumn{9}{|c|}{ NAES } \\
\hline & \multicolumn{3}{|c|}{ Men and Women } & \multicolumn{3}{|c|}{ Women } & \multicolumn{3}{|c|}{ Men } \\
\hline & B & SE & $\boldsymbol{\beta}$ & B & SE & $\boldsymbol{\beta}$ & B & SE & $\boldsymbol{\beta}$ \\
\hline Children & $\begin{array}{c}- \\
0.26^{* * *}\end{array}$ & 0.03 & -0.12 & $-0.27 * * *$ & 0.04 & -0.12 & $-0.23 * * *$ & 0.05 & -0.10 \\
\hline Traditionalism & 0.01 & 0.01 & 0.01 & 0.00 & 0.01 & 0.00 & $0.02 \dagger$ & 0.01 & 0.01 \\
\hline Ideology & $\begin{array}{c}- \\
0.07 * * *\end{array}$ & 0.01 & -0.03 & $-0.11 * * *$ & 0.02 & -0.04 & -0.02 & 0.02 & -0.01 \\
\hline Tradition x Child & $0.02 * * *$ & 0.01 & 0.02 & $0.01 \dagger$ & 0.01 & 0.02 & $0.03 * *$ & 0.01 & 0.03 \\
\hline Ideology x Child & $0.04 * * *$ & 0.01 & 0.07 & $0.05 * * *$ & 0.01 & 0.07 & $0.03 *$ & 0.02 & 0.05 \\
\hline Age & $0.01^{* * *}$ & 0.00 & 0.08 & $0.02 * * *$ & 0.00 & 0.11 & $0.01 * * *$ & 0.00 & 0.06 \\
\hline Married & $0.48 * * *$ & 0.02 & 0.09 & $0.55 * * *$ & 0.03 & 0.11 & $0.41^{* * *}$ & 0.04 & 0.08 \\
\hline Education & $0.17^{* * *}$ & 0.01 & 0.15 & $0.17 * * *$ & 0.01 & 0.15 & $0.18 * * *$ & 0.01 & 0.17 \\
\hline Income & $0.14^{* * *}$ & 0.01 & 0.11 & $0.14^{* * *}$ & 0.01 & 0.11 & $0.13^{* * *}$ & 0.01 & 0.11 \\
\hline Constant & $0.71 * * *$ & 0.06 & & $0.65 * * *$ & 0.09 & & $0.72 * * *$ & 0.09 & \\
\hline R-square & & 0.08 & & & 0.08 & & & 0.07 & \\
\hline $\mathbf{N}$ & & 5, 302 & & & 0,575 & & & 4,727 & \\
\hline
\end{tabular}

Notes: ${ }^{*} \mathrm{p}<0.05 ;{ }^{* *} \mathrm{p}<0.01 ;{ }^{* * *} \mathrm{p}<0.001 ; \dagger<0.10$ (two-tailed tests) 
Table 4: Results from OLS Regression of Following Politics on Number of Children, Religious Traditionalism, and Political Ideology

\begin{tabular}{|c|c|c|c|c|c|c|c|c|c|}
\hline & \multicolumn{9}{|c|}{ NAES } \\
\hline & \multicolumn{3}{|c|}{ Men and Women } & \multicolumn{3}{|c|}{ Women } & \multicolumn{3}{|c|}{ Men } \\
\hline & B & SE & $\boldsymbol{\beta}$ & B & SE & $\boldsymbol{\beta}$ & B & SE & $\boldsymbol{\beta}$ \\
\hline Children & $-0.08 * * *$ & 0.01 & -0.10 & $-0.09 * * *$ & 0.02 & -0.10 & $-0.05^{* *}$ & 0.02 & -0.07 \\
\hline Traditionalism & $0.01 *$ & 0.00 & 0.01 & $0.02 * * *$ & 0.00 & 0.03 & 0.00 & 0.00 & 0.00 \\
\hline Ideology & $0.03 * * *$ & 0.01 & 0.03 & 0.00 & 0.01 & 0.00 & $0.05 * * *$ & 0.01 & 0.05 \\
\hline $\begin{array}{l}\text { Tradition x } \\
\text { Child }\end{array}$ & 0.00 & 0.00 & 0.00 & 0.00 & 0.00 & -0.01 & $0.01 \dagger$ & 0.00 & 0.02 \\
\hline $\begin{array}{l}\text { Ideology x } \\
\text { Child }\end{array}$ & $0.02 * * *$ & 0.00 & 0.07 & $0.02 * * *$ & 0.01 & 0.08 & 0.01 & 0.01 & 0.04 \\
\hline Age & $0.01 * * *$ & 0.00 & 0.25 & $0.02 * * *$ & 0.00 & 0.29 & $0.01 * * *$ & 0.00 & 0.21 \\
\hline Married & $0.02 * *$ & 0.01 & 0.01 & $0.03 *$ & 0.01 & 0.01 & $0.03^{*}$ & 0.01 & 0.02 \\
\hline Education & $0.08 * * *$ & 0.00 & 0.20 & $0.08 * * *$ & 0.00 & 0.19 & $0.08 * * *$ & 0.00 & 0.22 \\
\hline Income & $0.06 * * *$ & 0.00 & 0.13 & $0.05 * * *$ & 0.00 & 0.11 & $0.05 * * *$ & 0.00 & 0.12 \\
\hline Constant & $1.67 * * *$ & 0.02 & & $1.60 * * *$ & 0.04 & & $1.81^{* * *}$ & 0.03 & \\
\hline R-square & & 0.14 & & & 14 & & & 0.14 & \\
\hline $\mathbf{N}$ & & 2,683 & & &, 532 & & & 19,151 & \\
\hline
\end{tabular}

Notes: ${ }^{*} \mathrm{p}<0.05 ;{ }^{* *} \mathrm{p}<0.01 ;{ }^{* * *} \mathrm{p}<0.001 ; \dagger<0.10$ (two-tailed tests) 
Table 5: Results from OLS Regression of Women Discussing Politics with Friends or Family on Number of Children, Religious Traditionalism, and Political Ideology

\begin{tabular}{|c|c|c|c|c|c|c|c|c|c|}
\hline & \multicolumn{9}{|c|}{ NAES } \\
\hline & \multicolumn{3}{|c|}{ Liberals } & \multicolumn{3}{|c|}{ Moderates } & \multicolumn{3}{|c|}{ Conservatives } \\
\hline & $\mathbf{B}$ & SE & $\boldsymbol{\beta}$ & B & SE & $\boldsymbol{\beta}$ & B & SE & $\boldsymbol{\beta}$ \\
\hline Children & $-0.17 * * *$ & 0.03 & -0.07 & $-0.12 * * *$ & 0.03 & -0.05 & $-0.09 * *$ & 0.03 & -0.05 \\
\hline Traditionalism & $-0.08 * *$ & 0.03 & -0.05 & $-0.04 * *$ & 0.01 & -0.03 & $0.04 * *$ & 0.01 & 0.04 \\
\hline $\begin{array}{l}\text { Tradition } \mathrm{x} \\
\text { Child }\end{array}$ & $0.03 \dagger$ & 0.02 & 0.03 & $0.02 \dagger$ & 0.01 & 0.02 & 0.00 & 0.01 & 0.00 \\
\hline Age & $0.02 * * *$ & 0.00 & 0.11 & $0.02 * * *$ & 0.00 & 0.12 & $\begin{array}{c}0.01 * * \\
*\end{array}$ & 0.00 & 0.09 \\
\hline Married & $0.41 * * *$ & 0.07 & 0.08 & $0.53 * * *$ & 0.05 & 0.11 & $\begin{array}{c}0.65^{* *} \\
*\end{array}$ & 0.05 & 0.12 \\
\hline Education & $0.23 * * *$ & 0.02 & 0.21 & $0.15^{* * *}$ & 0.01 & 0.14 & $\begin{array}{c}0.13^{* *} \\
*\end{array}$ & 0.01 & 0.11 \\
\hline Income & $0.11^{* * *}$ & 0.02 & 0.08 & $0.13^{* * *}$ & 0.01 & 0.11 & $\begin{array}{c}0.16^{* *} \\
*\end{array}$ & 0.01 & 0.13 \\
\hline Constant & $0.51 * * *$ & 0.15 & & 0.12 & 0.11 & & $0.34 * *$ & 0.12 & \\
\hline R-square & & .10 & & & .08 & & & 0.07 & \\
\hline $\mathbf{N}$ & & 750 & & & 086 & & & 11,739 & \\
\hline
\end{tabular}

Notes: ${ }^{*} \mathrm{p}<0.05 ;{ }^{* *} \mathrm{p}<0.01 ;{ }^{* * *} \mathrm{p}<0.001 ; \dagger<0.10$ (two-tailed tests)

\section{ENDNOTES}

${ }^{1}$ Evangelical Christians, conservative Protestants, and religious traditionalists (Layman 2001) will be used interchangeably in this author's work, using the preferred label when citing a respective author. Evangelical or conservative Protestants and religious traditionalists tend to report having a born-again experience, believe in a literal translation of the Bible, and ascribe to orthodox beliefs, while mainline Protestants or religious modernists, usually belonging to Methodist, Episcopalian, or Presbyterian churches, usually do not view the Bible as the literal 
word of God and focus more on social justice issues on earth rather than an emphasis on personal salvation and the afterlife (Layman 2001; Smith 1990).

2 The term “Quiverfull” is based upon Psalm 127, which indicates parents should want as many sons as a warrior desires arrows in his quiver (Hagerty 2009).

${ }^{3}$ Annenberg Public Policy Center. 2004 National Annenberg Election Survey. University of Pennsylvania.

${ }^{4}$ The models performed similarly when NAES respondents over the age of 65 were dropped from the analysis, with the magnitude of some of the co-efficients changing slightly due to difference in mean number of children.

${ }^{5}$ Removing ideology from the voting model and setting it as a grouping variable resulted in number of children completely dropping from significance, and since it was the variable of interest, this model will not be examined here. Because the interaction between traditionalism and number of children was not significant in the original following politics model, it is not surprising that it also was not significant when the sample was then split by ideology. 